\title{
Geotechnical Characteristics of Benin Formation, Owerri Imo State, Nigeria
}

\author{
C.C.Z. Akaolisa, ${ }^{1}$ (D) , J.C. Oparah ${ }^{1}$ (D) , O. E Agbasi, , , ${ }^{(D}$ \\ ${ }^{1}$ Department of Geology, Federal University of Technology, P.M.B 1526 Owerri, Nigeria \\ 2Department of Physics, Michael Okpara University of agriculture, Umudike, Nigeria
}

\section{Keywords}

Bearing Ratio

Liquid Limit

Linear Shrinkage

Moisture

Plastic Limit

\begin{abstract}
A good road network consists of a constant stretch of asphalt laid down for a smooth ride. The spot in the smooth ride on the pavement is commonly referred to as "pavement failure." Soil type, load bearing capacity of materials, zone of vulnerability, resistance to permeation, compressibility, shrinkage limit, and other details are frequently required in order to construct a very good and solid foundation for the planned bridge site. In Nigeria, numerous factors contribute to the failure of road construction projects. They are primarily insufficient research on subgrade and other pavement materials (sub-base and base courses) prior to the start of road projects; flawed engineering, including a poor drainage system and supervision throughout road construction; and shoddy workmanship that was superimposed with asphaltic concrete to improve strength. Within the Niger Delta basin, the study area is located between latitude $5.485^{\circ} \mathrm{N}$ and longitude $7.035^{\circ} \mathrm{E}$. The Benin Formation underpins the study area. It is composed primarily of friable sands, conglomerates, very coarse sandstone, and isolated gravel units, as well as intercalation of Pliocene to Miocene shale/clay lenses. Natural Moisture Content (NMC), Linear Shrinkage (LS), Particle Size Distribution, and California Bearing Ratio were among the laboratory tests performed on samples collected at failed and stable sections of some selected road segments (CBR). When compared to the stable sections, the NMC along the failed sections was on the high side (ranging from 13.11 percent to 26.89 percent) (ranging from 11.11 percent to 16.40 percent). The majority of the tested soils passed the $0.075 \mathrm{~mm}$ sieve with a percentage greater than the Federal Ministry of Works and Housing's maximum of $35 \%$ for subgrade materials. The maximum dry density (MDD) for the samples at failed and stable sections was $1550 \mathrm{~kg} / \mathrm{m} 3$ to $1860 \mathrm{~kg} / \mathrm{m} 3 ; 1650 \mathrm{~kg} / \mathrm{m} 3$ to $1980 \mathrm{~kg} / \mathrm{m} 3$; and the Optimum Moisture Content (OMC) was $8.30 \%$ to $20.30 \%$. The soaked CBR values ranged from 2 to 17 percent, while the unsoaked values ranged from 4 to 25 percent.
\end{abstract}

\section{Introduction}

Soil is the section of the earth's crust where plants grow [1]. All soil is formed by weathering rocks (parent materials) and minerals [2]. These minerals include quartz, mica, feldspar, homblende, calcite, and gypsum. The parent material or parent rocks from which a soil originates impacts the engineering behavior and swelling qualities of a soil required for construction applications [3, 4].

Nevertheless, the need for enhancing soil engineering qualities for structural applications has been acknowledged. Soil enhancement could be accomplished by alteration, fortification, or both $[5,6,7]$. Soil alteration is the addition of a modifier (cement, lime, etc.) to a soil to alter its physical properties, whereas soil stabilization is the treatment of soils to enhance their performance and durability towards the point at which they are wholly suitable for construction beyond their initial classification $[8,9,10,11]$. Many soil materials, such as literite gravel and pizzollite, which are suitable for gravel road construction, are found in tropical areas around the world, including Nigeria [12]. When a lit includes a large number of clay components, its strength and stability under load cannot be guaranteed, especially when moisture is present [13]. These soil terminologies are common in many tropical locations, including Nigeria, where sourcing for different soils may be economically inadvisable and it is better to change the existing soil to achieve the intended goal. Cement and lime have historically been the two primary materials used for soil stabilization [14, 15]. Because of the dramatic increase in the cost of energy during the 1970's, the price of these materials has risen rapidly.
Subsurface geotechnical explorations are extremely valuable in characterizing subsurface geologic materials; details such as soil type, ductility of materials, zone of vulnerability, resistance to permeation, deformability, plasticity index, and so on are frequently required in order to design a very good and strong foundation for the proposed site. The goal of this work is to determine the location of soil in relation to geotechnical properties in the failure of the road around Owerri.

\section{Geology and Location of the Study Area}

Within the Niger Delta basin, the study area is located between latitude $5.485^{\circ} \mathrm{N}$ and longitude $7.035^{\circ} \mathrm{E}$ (Fig 1.). It is accessible by road via different routes such as Onitsha, Port Harcourt, and the Aba Expressway, making it a pivotal city in Nigeria's Southeastern region.

The Benin Formation underpins the study area (Fig 2.). It is composed primarily of friable sands, conglomerates, very coarse sandstone, and isolated gravel units, as well as intercalation of Pliocene to Miocene shale/clay lenses. 

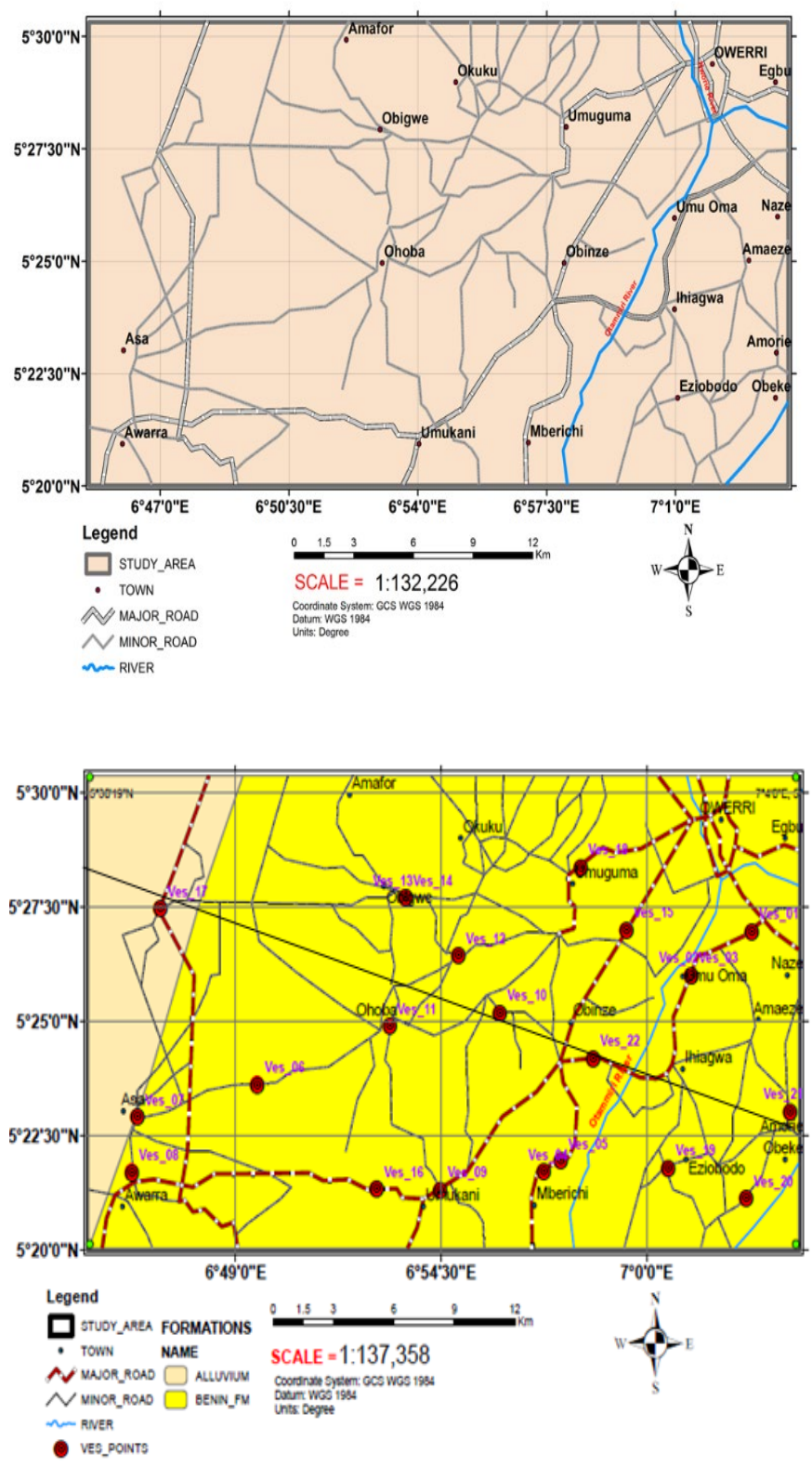

\section{Methodology}

Three samples were collected from the field and examined closely. The first stage of sample collection entails the selection and categorisation of the study area using a topographic map. The second stage included a reconnaissance survey, followed by detailed geological surveying utilizing geological tools such as:
1. Location map
2. Geologic map
3. Geologic hammer
4. Hand lens
5. Compass clinometer
6. Measuring tape
7. Sample bags
8. Notebook for Field Notes

The laboratory analysis of the sample collected from the field was the third phase in the data analysis process. Both soil and rock samples were tested for grain size distribution, sieve analysis, compaction test, and atterberg or consistency limit test (liquid and plastic limits) on the samples (both soil and rock). The soil samples were duly dried using a sieve of $19.5 \mathrm{~mm}$ and finally quartered into suitable quantities required for each analysis using a riffle box (12.5 $\mathrm{mm}$ slot). The laboratory tests were analysed carefully to achieve accuracy. Each sample material for the CBR test was soaked for 48 hours. The tests consist of:

\subsection{The Atterberg Limit Test}

The Atterberg Test, also known as the Consistency Limit Test, determines the moisture content at which the soil will flow under its own height. It delineates the boundaries of various states of plastic soil consistency [16]. It is used to determine soil plasticity. The Atterberg limit test is used to calculate the liquid limit, plastic limit, plasticity index, liquidity index, and relative consistency.

a) Plastic Limit: This is the percentage of moisture at which a soil can be slid without breaking into three-millimeter-diameter threads ( 3 $\mathrm{mm}$ ). The Cassagrande apparatus consists of a mortar and pestle or oven, a grooving tool, a glass plate, a water weighing balance, and containers.

This is a measure of soil plasticity. The plasticity index PI measures the size of the water content range in which the soil exhibits plastic qualities. The PI is defined as the difference between the liquid and plastic limits, i.e. $\mathrm{PI}=(\mathrm{LL}-\mathrm{PL})$. Soils with a high PI tend to be clay, those with a low PI likely to be silt, and those with a PI of zero (now plastic) tend to be devoid of silt or clay.

$\mathrm{PI}=\mathrm{LL}-\mathrm{PL}$

Where,

PL $=$ Plastic Limit, $\mathrm{LL}=$ Liquid Limit, PI = Plasticity Index

b) Liquid Limit Test: The moisture content at which the soil begins to behave like a fluid when subjected to a specific set of blows is measured. A fraction of the paste was remolded on a glass plate, placed in the liquid limit apparatus, and grooved with a standard grooving method to prevent trapped air. The liquid limit is defined by the moisture content at twenty-five blows. A Cassagrande device, glass plates, containers, a weighing balance, and an oven are among the materials used.

The water content of the soils in moisture cans was evaluated after 16 hours of oven drying, and a graph of the number of blows at the horizontal axis was plotted versus the percentage moisture content (w \%). Draw the straight line that best fits the displayed points and calculate the liquid limit LL as the water content at 25 drops.

$\mathrm{W}_{\mathrm{L}}=\mathrm{W}_{1}-\mathrm{W}_{2}$

Where;

$\mathrm{WL}=$ Moisture Content(gm), $\mathrm{W}_{1}=$ Weight of Wet Sample + Container, $\mathrm{W}_{2}=$ Weight of Dried Sample + Container

$\mathrm{LL}=\frac{\mathrm{W}_{1}}{\mathrm{~W}_{2}} \times 100$

c) Linear Shrinkage: This test delineates the shrinkage and swelling potential of geologic deposits. Materials used are: shrinkage dish, oven, mercury, electric balance, sieve \#40, spatula, and containers.

When soil loses water, either naturally or in the laboratory, it changes from a liquid to a plastic state, then to a semi-solid state, and eventually to a solid form. The decline in water content impacts to the volume as well. Nevertheless, over a certain point, the moisture decrease has no further effect on volume. A shrinkage list contains both a quantitative indicator of how much can change before any significant volume change happens and an indication of volume change.

In the calculation of linear shrinkage LS $\%$ the following formular is applied 
$\operatorname{LS}(\%)=\left[\mathrm{I}-\frac{\mathrm{LS}}{\mathrm{L}}\right] \times 100$

Where

$\mathrm{L}=$ Length of the mould which is also the initial length before shrinking take place, LS = Longitudinal shrinkage of the specimen in $(\mathrm{mm})$

\subsection{Grading (Sieve Analysis)}

This was done in order to determine the distribution of grain sizes within the soil samples collected. The outcome was used to determine the soil's sorting characteristics. A British standard sieve, a heavyduty balance, a wire brush, rubber, an electric oven, a large metal tray, sample containers of known weight, a trowel, and water were used in the analysis. The samples were oven dried to remove any moisture. Following that, $500 \mathrm{~g}$ of samples were placed in a known-weight container and labeled. Water was added to the sample, which was then left to stand for 24 hours. The soaked sample was then washed through a $20-\mathrm{mm}$ sieve to remove any fine particles from the water. The washed sample was oven dried for twenty hours, and the weight of the sample and container were calculated. Removing the weight of the container from the weight of the oven-dried sample yielded the weight of the sample. The weight of the fine material washed off from the original samples was computed by deducting the weight of the washed and oven dried sample from the weight of the original sample and the sieves were stacked with the larger aperture sieve at the top and the smaller aperture sieve at the bottom. The samples were passed through the sieves, and the weight retained on each sieve was calculated with a heavy-duty balance.

3.3. Maximum Dry Density/Optimum Moisture Content Compaction Tests

The Maximum Dry Density test is an experimental technique for evaluating the ideal moisture content at which a given soil type will be most dense and achieve its maximum dry density [17, 18]. It entails compacting soil with a known moisture content into a cylindrical mold with a collar of standard height and diameter, using a controlled magnitude of compactive effort. The soil is usually poured into the mold in a certain number of equal layers, each of which receives a certain number of blows from a standard-weighted hammer at a specified height.

The percentage of water existing in a soil mass at which a particular compaction force can dry the soil mass to its maximum dry weight is referred to as the Optimum Compaction test. To determine the OMC and MDD of soil masses, standard proctor and modified proctor tests are used. The size and weight of the hammer used to compact the soil mass differ between the two. OMC can be performed using one of three methods: the Sand Cone Test, the Shelby Tube Test, or the Nuclear Gauge Test.

\subsection{The California Bearing Ratio}

This is the penetration test used to determine the strength of the subgrade of roads and pavement [14]. The Laboratory CBR apparatus is made up of a $150 \mathrm{~mm}$ diameter mold with a base plate and a collar, a loading frame, and dial gauges for measuring penetration values and expansion on soaking. If a soaked (wet) measurement is required, the specimen in the mold is soaked in water for four days and the results are recorded. The surcharge weight is placed on top of the specimen in the mold, and the assembly is placed beneath the loading frame's plunger [15]. A standard plunger with a diameter of $50 \mathrm{~mm}$ is used to apply load to the sample at a rate of $1.25 \mathrm{~mm} / \mathrm{min}$, and a load plunger curve is drawn.

\section{Data Analysis/ Interpretation of Results}

The results of geotechnical analysis are shown in Tables 1, 2 and 3 with Figure 3. For sieve analysis, the results from the table show that the values of S2 and S3 were beyond the specified desired limits, which indicates poor subgrade material, while that of S1 was within the desired limit, which indicates good subgrade material according to the general specifications for roads and bridges under FMW, Nigeria (2007 Revised). The soil description for S1 is silt, sand, and gravel with clay fines, while S2 and S3 are high-compressibility silt clays.
For the compaction test, the results from the table show that the values of OMC for S1-S3 were $14.4 \%, 14.6 \%$, and $16.4 \%$, respectively. MDD values were $1.776 \mathrm{~g} / \mathrm{cm} 3,1.713 \mathrm{~g} / \mathrm{cm} 3$, and $1.692 \mathrm{~g} / \mathrm{cm} 3$, with no specified desired limit.According to the AASHTO Classification, the MDD was within the range of 1.7-2.16 for S3, while S1-S2 was 1.36-1.84. Soil compaction improves its properties, resulting in more mechanically stable pathways that are better suited to their purpose. The failure of the pavement can be attributed to poor compaction of the sub-base course. Other causes included a lack of drainage, which could lead to surface water stagnation, and a thickness of the subbase that was discovered to be $350 \mathrm{~mm}$ greater than the required 150 $\mathrm{mm}$ to $250 \mathrm{~mm}$ standard.

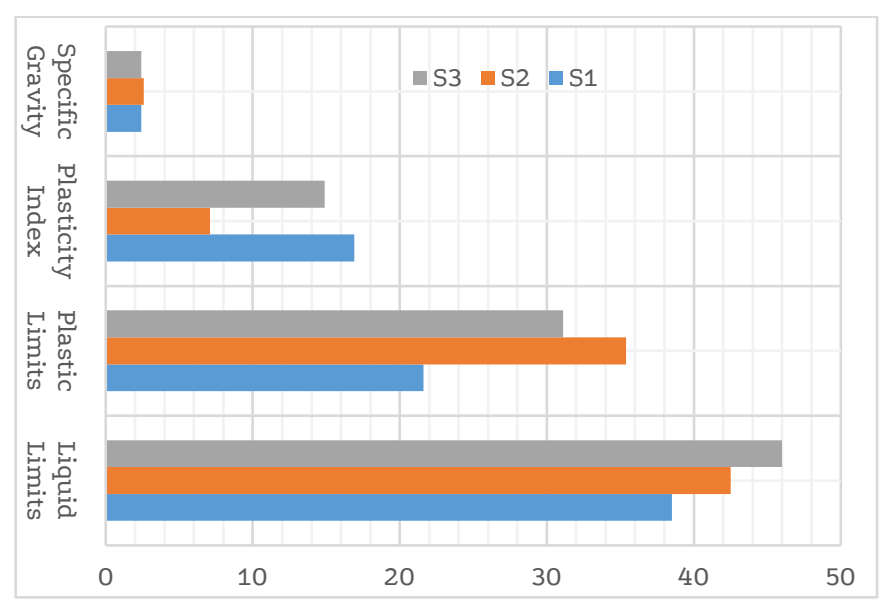

Figure 3. Grain analysis for each soil samples

Table 1. Geotechnical analysis for S1 $01 \mathrm{~A} \& \mathrm{~B}$

\begin{tabular}{|c|c|c|c|}
\hline S/NO & $\begin{array}{l}\text { PARAMETER } \\
\text { TESTED }\end{array}$ & $\begin{array}{l}\text { TEST } \\
\text { RESULTS }\end{array}$ & $\begin{array}{l}\text { SPECIFIED } \\
\text { DESIRED LIMITS }\end{array}$ \\
\hline \multirow[t]{2}{*}{1} & Sieve Analysis & & $\begin{array}{l}\text { Subgrade } \\
\text { material }\end{array}$ \\
\hline & $\%$ passing 200 & $26.0 \%$ & $<$ or $=35 \%$ \\
\hline \multirow[t]{4}{*}{2} & Atterberg Limits & & \\
\hline & Liquid Limits & 38.5 & <or $=50$ \\
\hline & Plastic Limits & 21.6 & -------- \\
\hline & Plasticity Index & 16.9 & $<o r+30$ \\
\hline \multirow[t]{3}{*}{3} & Compaction Test & & \\
\hline & $\mathrm{OMC}$ & $14.4 \%$ & -------- \\
\hline & MDD & $1.776 \mathrm{~g} / \mathrm{cm}^{3}$ & -------- \\
\hline 4 & CBR & $\begin{array}{l}2.1 \% \\
\text { (Soaked } \\
48 \mathrm{hrs} \text { ) }\end{array}$ & $\begin{array}{l}>3 \% \text { after } 48 \mathrm{hrs} \\
\text { soaked }\end{array}$ \\
\hline 5 & Linear Shrinkage & $10.7 \%$ & $0-8 \%$ \\
\hline 6 & Specific Gravity & 2.407 & - \\
\hline 7 & Bulk Density & $\mathrm{N} / \mathrm{A}$ & - \\
\hline 8 & Natural Moisture & $\begin{array}{l}18.2 \% \text { (by } \\
\text { moisture } \\
\text { speedy } \\
\text { tester } \\
\text { method) }\end{array}$ & - \\
\hline
\end{tabular}

For the Atterberg Limits test, the results from the table show that the liquid limit values for S1-S3 were 38.5\%, 42.5\%, and 46\%, respectively, which is within the specified desired limits of less than or equal to $50 \%$. The plasticity index is the key property in achieving low hydraulic conductivity. The plastic limit values for the three samples (S1-S3) were $21.6 \%, 35.4 \%$, and $31.1 \%$, respectively, with no specified desired limits. While the plastic index values were $16.9 \%, 7.1 \%$, and $14.9 \%$, respectively, they were within the specified desired limits of less than $30 \%$. For S3 and S2, the plasticity index of the samples falls within the range of $15-25 \%$, so the sediments have medium swelling potential, whereas for S1, the plasticity index was below 15\%, implying low swelling potential. 
Table 2. Geotechnical analysis for S2 01 A \& B

\begin{tabular}{|c|c|c|c|}
\hline $\mathrm{S} / \mathrm{NO}$ & $\begin{array}{l}\text { PARAMETER } \\
\text { TESTED }\end{array}$ & $\begin{array}{l}\text { TEST } \\
\text { RESULTS }\end{array}$ & $\begin{array}{l}\text { SPECIFIED } \\
\text { DESIRED } \\
\text { LIMITS }\end{array}$ \\
\hline 1 & Sieve Analysis & $42,2 \%$ & $\begin{array}{l}\text { Subgrade } \\
\text { material }\end{array}$ \\
\hline 2 & Atterberg Limits & $42.2 \%$ & \\
\hline & Liquid Limits & 42.5 & <or $=50$ \\
\hline & Plastic Limits & 35.4 & --------- \\
\hline & Plasticity Index & 7.1 & $<o r+30$ \\
\hline 3 & Compaction Test & & \\
\hline & $\begin{array}{l}\mathrm{OMC} \\
\mathrm{MDD}\end{array}$ & $\begin{array}{l}14.6 \% \\
1.713 \mathrm{~g} / \mathrm{cm}^{3}\end{array}$ & -------- \\
\hline 4 & CBR & $\begin{array}{l}3.4 \% \text { (Soaked } \\
48 \mathrm{hrs} \text { ) }\end{array}$ & $\begin{array}{l}>3 \% \text { after } \\
48 \mathrm{hrs} \\
\text { soaked }\end{array}$ \\
\hline 5 & $\begin{array}{l}\text { Linear } \\
\text { Shrinkage }\end{array}$ & $6.4 \%$ & $0-8 \%$ \\
\hline 6 & Specific Gravity & 2.586 & - \\
\hline 7 & Bulk Density & $\mathrm{N} / \mathrm{A}$ & - \\
\hline 8 & $\begin{array}{l}\text { Natural } \\
\text { Moisture }\end{array}$ & $\begin{array}{l}24.2 \% \text { (by } \\
\text { moisture } \\
\text { speedy tester } \\
\text { method) }\end{array}$ & - \\
\hline
\end{tabular}

Table 3. Geotechnical analysis for S3 01 A \& B

\begin{tabular}{|c|c|c|c|}
\hline $\mathrm{S} / \mathrm{NO}$ & $\begin{array}{l}\text { PARAMETER } \\
\text { TESTED }\end{array}$ & $\begin{array}{l}\text { TEST } \\
\text { RESULTS }\end{array}$ & $\begin{array}{l}\text { SPECIFIED } \\
\text { DESIRED } \\
\text { LIMITS }\end{array}$ \\
\hline 1 & $\begin{array}{l}\text { Sieve Analysis } \\
\% \text { passing } 200\end{array}$ & $49.7 \%$ & $\begin{array}{l}\text { Subgrade } \\
\text { material } \\
<\text { or }=35 \%\end{array}$ \\
\hline 2 & $\begin{array}{l}\text { Atterberg Limits } \\
\text { Liquid Limits } \\
\text { Plastic Limits } \\
\text { Plasticity Index }\end{array}$ & $\begin{array}{l}46.0 \\
31.1 \\
14.9\end{array}$ & $\begin{array}{l}<o r=50 \\
-<o r+30\end{array}$ \\
\hline 3 & $\begin{array}{l}\text { Compaction Test } \\
\text { OMC } \\
\text { MDD }\end{array}$ & $\begin{array}{l}16.4 \% \\
1.692 \mathrm{~g} / \mathrm{cm}^{3}\end{array}$ & -------- \\
\hline 4 & CBR & $\begin{array}{l}16.2 \% \\
\text { (Soaked } \\
48 \mathrm{hrs} \text { ) }\end{array}$ & $\begin{array}{l}>3 \% \text { after } \\
48 \mathrm{hrs} \text { soaked }\end{array}$ \\
\hline 5 & $\begin{array}{l}\text { Linear } \\
\text { Shrinkage }\end{array}$ & $11.1 \%$ & $0-8 \%$ \\
\hline 6 & Specific Gravity & 2.413 & - \\
\hline 7 & Bulk Density & $\mathrm{N} / \mathrm{A}$ & - \\
\hline 8 & $\begin{array}{l}\text { Natural } \\
\text { Moisture }\end{array}$ & $\begin{array}{l}25.4 \% \text { (by } \\
\text { moisture } \\
\text { speedy } \\
\text { tester } \\
\text { method) }\end{array}$ & - \\
\hline
\end{tabular}

For the California Bearing Ratio test, the results from the table show that values of CBR for the three samples were $2.1 \%, 3.4 \%$, and $16.2 \%$ soaked for 48 hours, respectively. The values of S1 fell below the specified desired limit, while those of S2 and S3 were within the desired limits of greater than $3 \%$ after 48 hours of soaking.

\section{Conclusion}

The Benin Formation underpins the research area. It is composed primarily of friable sands, conglomerates, very coarse sandstone, and isolated gravel units, with intercalation of Pliocene to Miocene shale/clay lenses. Three samples were collected at the failed and stable portions of some selected road segments and subjected to laboratory tests such as Natural Moisture Content (NMC), Linear Shrinkage (LS), Particle Size Distribution, and California Bearing Ratio (CBR).

When compared to the stable sections, the NMC along the failed sections was on the high side (ranging from 13.11 percent to 26.89 percent) (ranging from 11.11 percent to 16.40 percent).
The majority of the tested soils passed the $0.075 \mathrm{~mm}$ sieve with a percentage greater than the Federal Ministry of Works and Housing's maximum of $35 \%$ for subgrade materials.

\section{Declaration of Conflict of Interests}

The authors declare that there is no conflict of interest. They have no known competing financial interests or personal relationships that could have appeared to influence the work reported in this paper.

\section{References}

[1.] Areola, O., Soil, In Barbou, K. M. (edt) Nigeria in Maps. Hodder and Stoughton, London. (1982).

[2.] Phummiphan, I., Horpibulsuk, S., Rachan, R., Arulrajah, A., Shen, S.L., Chindaprasirt. P., High Calcium Fly Ash Geopolymer Stabilized Lateritic Soil and Granulated Blast Furnace Slag Blends as a Pavement Base Material. Journal of Hazardous Materials 341 (2018) 257-267.

[3.] Ashis, K.B., Compaction characteristics of fine grained soil and rice husk ash mixture, International Journal of Geotechnical Engineering, 8(2) (2014) 121-129.

[4.] Hejazi, S.M., Sheikhzadeh, M., Abtahi, S.M., Zadhoush, A., A simple review of soil reinforcement by using natural and synthetic fibers, Construction and Building Materials, 30 (2012) 100-116.

[5.] Shahram, P., Bujang, K.H., A review of alternatives traditional cementitious binders for engineering improvement of soils, International Journal of Geotechnical Engineering, 5 (2016) 9 14.

[6.] Abd, T.A., Fattah, M.Y., Aswad, M.F, Improvement of Soft Clayey Soil by Bio-polymer, Engineering and Technology Journal 39 (08) (2021) 1301-1306.

[7.] Khalaf, F.Kh., Hafez, M.A., Fattah, M.Y., Al-Shaikli, M.S., A Review Study on the Optimizing the Performance of Soil Using Nanomaterials, Advances in Industrial Engineering and Management (AIEM), 9(2), (2020) 1-10.

[8.] Goodarzi, A.R., Akbari, H.R., Salimi. M, Enhanced Stabilization of Highly Expansive Clays by Mixing Cement and Silica Fume. Applied Clay Science 132-133 (2016) 675-684.

[9.] Alrubaye, A.J., Hasan, M., Fattah, M.Y., Stabilization of Soft Kaolin Clay with Silica Fume and Lime, International Journal of Geotechnical Engineering, 11(1) (2017) 90-96,

[10.] Alrubaye, A.J., Hasan, M., Fattah, M.Y., Engineering Properties of Clayey Soil Stabilized with Lime, ARPN Journal of Engineering and Applied Sciences, 11(4) (2016) 2434-2441.

[11.] Fattah, M.Y., Al-Neami, M.A., Al-Suhaily, A.S.H., Strength Improvement of Soft Soil Treated Using Stone Columns, Engineering and Technology Journal, University of Technology, Iraq, 33(8) (2015) 1740-1756.

[12.] Ogbuefi, P.S., Nwaokafor, P., Njoku, I.J., Uzuegbunam, O.J., Elemental characterization of rice husk ash from local rice species in South Eastern Nigeria. Chemistry Africa, 3(12) (2020) $1-8$.

[13.] Osinubi, K.J., Medubi, A.B., Evaluation of cement and phosphatic waste admixture on tropical black clay for road foundation, Structural Engineering Analysis and Modeling, SEAM4, 2 (1997) 297-307. 
[14.] Cristelo, N., Glendinning, S., Fernandes, L., Pinto, A. T., Effects of alkaline-activated fly ash and Portland cement on soft soil stabilisation, Acta Geotechnica, 8 (2013) 395-405.

[15.] Goodarzi, A.R., Movahedrad, M., Stabilization/Solidifi cation of Zinc-Contaminated Kaolin Clay Using Ground Granulated Blast-Furnace Slag and Different Types of Activators. Applied Geochemistry 81 (2017) 155-165.

[16.] Abam, T.K.S., Osadebe, C.C., Omange, G.N., Influence of Geology on Pavement Performance: A Case Study of Shagamu- Benin City Road, South Western Nigeria, Global Journal of Geological Sciences, 3(1) (2005) 17-24.

[17.] Kekere, A. A., Lawal, L.O., Awotayo, G.P., Relationship between Geotechnical Properties and Road failures along Ilorin - Ajase Ipo Road Kwara State, Nigeria. Journal of Mechanical and Civil Engineering (IOSR-JMCE), 4(4) (2012) 1- 4.

[18.] Ndefo, O., Causes of Highway Failure in Nigeria. International. Journal of Engineering Science and Technology, 4(11) (2012) 6 11.

[19.] Odunfa, S.O., Owolabi, A.O., Aiyedun, P.O., Sadiq, O.M. Geotechnical Assessment of Pavement Failure along LagosIbadan Expressway. FUOYE Journal of Engineering and Technology, 3(2) (2018) 113-117.

[20.] Onunkwo, A.A., Alternative Source of Water Supply for Owerri Area. Journal of Environment and Earth Science 5(16) (2015) 127-135.

\section{How to Cite This Article}

Akaolisa, C.C.Z., Opara, J.C., Agbasi, O.E., Geotechnical Characteristics of Benin Formation, Owerri, Imo State, Nigeria. 2(2022), 4569.

https://doi.org/10.36937/ben.2022.4569 